\title{
EFEKTIVITAS BIAYA PENGGUNAAN AMPISILIN DAN SEFOTAKSIM PADA PASIEN ANAK DEMAM TIFOID
}

\author{
Cost-Effectiveness of Ampicillin and Cefotaxime Used \\ by Pediatric Patients with Typhoid Fever
}

\author{
Nurmainah, Siti Syabriyantini, Ressi Susanti \\ Program Studi Farmasi, Fakultas Kedokteran, Universitas Tanjungpura \\ Pontianak, Indonesia \\ (syabriyantini@gmail.com)
}

\begin{abstract}
ABSTRAK
Demam tifoid merupakan penyakit endemik yang angka kejadiannya masih tinggi di Indonesia. Pengobatan demam tifoid dapat dilakukan dengan cara pemberian terapi antibiotik, yaitu ampisilin dan sefotaksim. Penelitian ini dilakukan untuk mengetahui perbandingan efektivitas biaya penggunaan sefotaksim dan ampisilin pada pasien anak demam tifoid di RST TK II Kartika Husada Kubu Raya Tahun 2015. Metode yang digunakan dalam penelitian ini merupakan penelitian observasional dengan rancangan penelitian secara potong lintang (cross sectional) yang bersifat deskriptif. Pengumpulan data dilakukan secara retrospektif berdasarkan basis data rekam medik pasien demam tifoid yang dirawat inap di RST TK II Kartika Husada Kubu Raya periode Januari sampai dengan Desember 2015. Data efektivitas dan biaya pengobatan demam tifoid dianalisis secara ACER dan ICER. Dari hasil analisis data diperoleh nilai ACER pada penggunaan sefotaksim sebesar Rp.1.571.014,474 per efektivitas, sedangkan pada penggunaan ampisilin sebesar Rp.2.629.026,316 per efektivitas. Nilai ICER diperoleh sebesar Rp.513.002,632 per efektivitas. Kesimpulan dari penelitian ini adalah sefotaksim lebih cost effective dibandingkan ampisilin.
\end{abstract}

Kata kunci : Ampisilin, analisis efektivitas biaya, sefotaksim

\section{ABSTRACT}

Typhoid fever is an endemic disease which still has a high number of cases in Indonesia. Typhoid fever treatment can be done by giving antibiotics therapy in the form of ampicillin and cefotaxime. This study was conducted to compare the cost-effectiveness of ampicillin and cefotaxime use by pediatric patients with typhoid fever in RST TK II Kartika Husada Kubu Raya in 2015. The method used in this study was observational research with a descriptive cross-sectional research design. Data were collected retrospectively based on the medical records of patients with typhoid feverwho were hospitalized in RST TK II Kartika Husada Kubu Raya during the period of January to December 2015. The data showing typhoid fever treatment effectiveness and costs were analyzed using ACER and ICER. Results of the data analysis using ACER showed that the use of cefotaxime was Rp.1.571.014,474 per effectiveness, while the used of ampicillin was Rp.2.629.026,316 per effectiveness.Meanwhile, the ICER value was Rp.513.002,632 per effectiveness. This study concluded that cefotaxime is more cost effective than ampicillin. Keywords : Ampicillin, cost-effectiveness analysis, cefotaxime 


\section{PENDAHULUAN}

Demam tifoid merupakan penyakit endemik yang terdapat di negara berkembang. Di negara Sub Afrika kejadian demam tifoid sebesar 725 kasus/100.000 orang; Asia Tenggara sebesar 204 kasus/100.000 orang; Amerika Latin sebesar 105 kasus/100.000 orang; dan Oceania sebesar $22 \mathrm{ka-}$ sus/100.000 orang. ${ }^{1}$ Indonesia merupakan salah satu negara yang terletak di kawasan Asia Tenggara. Kejadian demam tifoid terus meningkat setiap tahunnya. Menurut data Riskesdas 2007 bahwa kasus demam tifoid di Indonesia sebanyak 1.600 kasus. $^{2}$ Sementara itu, berdasarkan Riskesdas 2010 jumlah kasus demam tifoid sebanyak 41.081 kasus. $^{3}$ Artinya selama tiga tahun terakhir telah terjadi peningkatan 25 kali lebih besar kasus demam tifoid. Demam tifoid disebabkan oleh bakteri Salmonella typhi (S. typhi). Gejala yang dirasakan seseorang pada minggu pertama setelah terinfeksi S. typhi adalah menunjukkan gejala demam seperti halnya gejala seseorang yang mengalami flu. Namun demikian, pada minggu kedua, demam akan terus meningkat secara progresif dan menetap mencapai $39-40{ }^{\circ} \mathrm{C} .{ }^{4}$ Untuk mengatasi demam tifoid diperlukan pilihan terapi yang tepat berupa terapi umum dan terapi pendukung. Terapi umum yang diberikan berdasarkan tatalaksana pengobatan demam tifoid adalah pemberian antibiotik sedangkan terapi pendukung berupa rehidrasi oral ataupun parenteral, antipiretik, dan pemberian nutrisi yang adekuat. ${ }^{5}$

Lini pertama pengobatan demam tifoid pada anak adalah penggunaan antibiotik kloramfenikol. Namun demikian, telah ditemukan adanya kasus resistensi kloramfenikol untuk demam tifoid. Resistensi pada $S$. typhi untuk kloramfenikol dilaporkan pertama kali terjadi di Inggris tahun 1950 dan di India tahun 1972 yang telah di kenal sebagai multi-drug resistant (MDR) S. typhi. Perkembangan selanjutnya, ditemukan resisten terhadap dua atau lebih golongan antibiotik utama untuk pengobatan demam tifoid seperti ampisilin, amoksilin, kotrimoksazol, dan fluorokuinolon. ${ }^{5,6,7} \mathrm{Namun}$ demikian, obat antibiotik tersebut masih diresepkan oleh beberapa klinisi. ${ }^{5,8}$

Perkembangan MDR S. typhi yang begitu cepat mengakibatkan mortalitas kasus demam tifoid pada anak meningkat. Untuk mengatasi permasalahan tersebut, maka diperlukan alternatif pe- ngobatan lain yaitu sefotaksim. ${ }^{9}$ Penelitian Gopal et al., menyimpulkan bahwa sefotaksim memiliki sensitivitas yang lebih baik dibandingkan dengan ampisilin. Sefotaksim juga memiliki tingkat kejadian resistensi yang lebih kecil dibandingkan ampisilin. ${ }^{10}$ Selain itu, lama rawat inap pada penggunaan sefotaksim juga lebih singkat dibandingkan dengan penggunaan ampisilin. Lama rawat inap pada pasien anak demam tifoid dianggap efektif apabila memenuhi target penggunaan antibiotik selama 4-14 hari. Disisi lain, biaya penggunaan sefotaksim diketahui lebih mahal dibanding penggunaan ampisilin. ${ }^{10}$ Oleh sebab itu, peneliti tertarik untuk mengetahui perbandingan efektivitas biaya penggunaan antibiotik ampisilin dan sefotaksim pada pasien anak demam tifoid di RST TK II Kartika Husada Kubu Raya tahun 2015.

\section{BAHAN DAN METODE}

Penelitian ini merupakan penelitian observasional dengan rancangan penelitian secara potong lintang (cross sectional). Penelitian ini dilaksanakan di RST TK II Kartika Husada Kubu Raya dan dilaksanakan selama tiga bulan, yaitu bulan April-Juni 2016. Pengumpulan data dilakukan secara retrospektif berdasarkan basis data rekam medik pasien demam tifoid yang dirawat inap di RST TK II Kartika Husada Kubu Raya periode Januari sampai dengan Desember 2015. Basis data rekam medik dilakukan validitas data dengan resep pasien demam tifoid. Validitas data yang dilakukan antara lain, nama pasien, umur, tanggal resep, nama obat, frekuensi dan dosis obat yang diberikan. Teknik pengambilan sampel dilakukan secara purposive sampling berdasarkan kriteria inklusi. Adapun kriteria inklusi penelitian meliputi pasien demam tifoid yang menjalani rawat inap di RST TK II Kartika Husada Kubu Raya, pasien anak dengan umur 1-14 tahun, pasien yang tepat diagnosis melalui tes widal, dan pasien yang mendapat pengobatan dengan antibiotik sefotaksim (iv) dan ampisilin (iv). Kriteria eksklusi penelitian yaitu meliputi pasien demam tifoid dengan penyakit penyerta, pasien yang pindah atau pulang paksa, dan data status pasien yang tidak lengkap, hilang serta tidak jelas terbaca.

Data yang dikumpulkan dicatat pada lembar pengumpul data. Data kuantitatif dalam penelitian ini berupa karakteristik subyek penelitian yaitu je- 
Tabel 1. Karakteristik Subyek Penelitian

\begin{tabular}{lcc}
\hline \multicolumn{1}{c}{ Karakteristik } & n & \% \\
\hline Usia & & \\
1 - 5 tahun & 16 & 53 \\
- 10 tahun & 9 & 30 \\
11 - 14 tahun & 5 & 17 \\
Jenis Kelamin & & \\
$\quad$ Laki-Laki & 15 & 50 \\
$\quad$ Perempuan & 15 & 50 \\
Kelas Perawatan & & \\
$\quad$ Kelas I & 4 & 13 \\
$\quad$ Kelas II & 14 & 47 \\
$\quad$ Kelas III & 12 & 40 \\
Frekuensi Tes Widal & & \\
1 Kali & 24 & 80 \\
2 Kali & 6 & 20 \\
\hline
\end{tabular}

nis kelamin pasien, umur pasien, jumlah pasien, jenis antibiotik, dan frekuensi uji laboratorium yang disajikan dalam bentuk data persentase. Data kuantitatif dalam penelitian ini berupa lama rawat inap dan data keuangan klaim kuitansi pengobatan berupa biaya penggunaan obat, biaya rawat inap, biaya visite dokter, biaya jasa perawat, dan biaya laboratorium. Data dianalisis dengan rumus Average Cost Effectiveness Ratio (ACER) dan Incremental Cost Effectiveness Ratio (ICER). Hasilnya disajikan berupa data deskriptif.

\section{HASIL}

Selama periode penelitian tersebut didapatkan sebanyak 30 sampel yang memenuhi kriteria inklusi dari 103 sampel. Hasil penelitian meliputi data karakteristik pasien yang terdiri dari usia, jenis kelamin, kelas perawatan, dan frekuensi uji widal. Adapun karakteristik subyek penelitian dapat dilihat pada Tabel 1. Angka kejadian demam tifoid terbanyak terjadi pada usia 1-5 tahun sebesar $53 \%$, sedangkan subyek yang berusia $6-10$ tahun dan 11-14 tahun secara berturut-turut yaitu sebesar 30\% dan $17 \%$. Hasil karakteristik subyek berdasarkan jenis kelamin pasien anak demam tifoid menunjukkan bahwa pasien perempuan sebanyak 50\% dan laki-laki sebanyak 50\%. Dari hasil karakteristik subyek berdasarkan kelas perawatan, diperoleh bahwa pasien anak demam tifoid paling banyak di kelas perawatan II sebesar $47 \%$. Diikuti pasien di kelas perawatan III dan I yang secara berturut-turut sebesar $40 \%$ dan $13 \%$. Hasil karakteristik subyek berdasarkan frekuensi uji widal menunjukkan bahwa terdapat $80 \%$ pasien anak demam tifoid melakukan uji widal 1 kali dan $20 \%$ menjalani tes widal sebanyak 2 kali.

Proses pengobatan pada pasien anak demam tifoid di RST TK II Kartika Husada Kubu Raya selain menggunakan antibiotik juga perlu mendapatkan terapi obat lain. Tampak pada Tabel 2, terapi obat lain yang digunakan diantaranya yaitu pemberian cairan infus sebanyak $100 \%$, obat analgetik-antipiretik sebanyak $100 \%$, antiulserasi sebanyak $53 \%$, multivitamin sebanyak $13 \%$, antiemetik sebanyak $23 \%$, suplemen sebanyak $23 \%$, laksatif sebanyak $10 \%$ dan probiotik sebanyak $13 \%$.

Selanjutnya dilakukan analisis efektivitas biaya (Cost Effectiveness Analysis/CEA). Beberapa tahapan yang dilakukan dalam analisis efektivitas biaya, pertama membandingkan biaya total rata-rata dengan efektivitas. Biaya rata-rata total dihitung dari biaya penggunaan obat, biaya visit dokter, biaya jasa perawat, biaya laboratorium, dan biaya rawat inap (secara lengkap dapat dili-

Tabel 2. Profil Penggunaan Obat Lainnya

\begin{tabular}{clccc}
\hline No. & \multicolumn{1}{c}{ Golongan Obat } & Nama Obat & Jumlah & \% \\
\hline 1 & Cairan Infus & RL OGB & 30 & 100 \\
2 & Analgesik - antipiretik & Paracetamol & 30 & 100 \\
3 & Antiulserasi & Ranitidin & 16 & 53 \\
4 & Multivitamin & Opinacea ${ }^{\circledR}$ & 3 & 10 \\
& & Elkana ${ }^{\circledR}$ & 1 & 3 \\
5 & Antiemetik & Ondancentron & 7 & 23 \\
6 & Suplemen & Imunos ${ }^{\circledR}$ & 3 & 10 \\
& & Zink & 4 & 13 \\
7 & Laksatif & Dulcolax ${ }^{\circledR}$ & 3 & 10 \\
8 & Probiotik & Lacto-B ${ }^{\circledR}$ & 1 & 3 \\
& & L-Bio ${ }^{\circledR}$ & 3 & 10 \\
\hline
\end{tabular}


Tabel 3. Analisis Rata-Rata Biaya Pengobatan Demam Tifoid pada Kelompok Ampisilin dan Sefotaksim

\begin{tabular}{lcc}
\hline \multirow{2}{*}{\multicolumn{1}{c}{ Variabel }} & \multicolumn{2}{c}{ Biaya Rata-Rata } \\
\cline { 2 - 3 } & Ampisilin & Sefotaksim \\
\hline 1. Biaya Penggunaan Obat & $\mathrm{Rp} \mathrm{303,801.00}$ & $\mathrm{Rp} \mathrm{460,208.00}$ \\
2. Biaya visit dokter & $\mathrm{Rp} \mathrm{145,384.00}$ & $\mathrm{Rp} \mathrm{166,176.00}$ \\
3. Biaya Jasa Perawat & $\mathrm{Rp} 71,923.00$ & $\mathrm{Rp} \mathrm{75,294.00}$ \\
4. Biaya laboratorium & $\mathrm{Rp} 39,846.00$ & $\mathrm{Rp} 47,882.00$ \\
5. Biaya rawat inap & $\mathrm{Rp} \mathrm{438,076.00}$ & $\mathrm{Rp} \mathrm{444,411.00}$ \\
\hline \multicolumn{1}{c}{ Total Biaya Medik } & Rp 999,030.00 & Rp 1,193,971.00 \\
\hline
\end{tabular}

Tabel 4. Persentase Efektivitas Terapi Antibiotik pada Pasien Anak Demam Tifoid di RST TK II Kartika Husada Kuburaya

\begin{tabular}{cccc}
\hline Antibiotik & $\begin{array}{c}\text { Pasien yang memenuhi target } \\
\text { lama rawat inap (4-14 hari) }\end{array}$ & $\begin{array}{c}\text { Jumlah Pasien } \\
(\mathbf{n}=\mathbf{3 0})\end{array}$ & $\begin{array}{c}\text { Efektivitas Terapi } \\
\mathbf{( \% )}\end{array}$ \\
\hline Ampisilin & 5 & 13 & 38 \\
Sefotaksim & 13 & 17 & 76 \\
\hline
\end{tabular}

Tabel 5. Hasil ACER

\begin{tabular}{cccc}
\hline Antibiotik & $\begin{array}{c}\text { Total Rata-Rata Biaya Medik } \\
\text { Langsung (Rp) }\end{array}$ & $\begin{array}{c}\text { Efektivitas Terapi } \\
\mathbf{( \% )}\end{array}$ & ACER (Rp) \\
\hline Ampisilin & 911.723 & 38 & 26.290 \\
Sefotaksim & 1.203 .383 & 76 & 15.710 \\
\hline
\end{tabular}

hat pada Tabel 3). Dari hasil perhitungan, biaya total rata-rata terapi demam tifoid pada pasien yang menggunakan antibiotik sefotaksim sebesar Rp.1.193.971,00 dan biaya total rata-rata terapi demam tifoid pada pasien yang menggunakan antibiotik ampisilin sebesar Rp.999.030,00. Efektivitas terapi dapat dilihat pada Tabel 4, bahwa efektivitas terapi dari penggunaan obat ampisilin sebesar 38\% sedangkan efektivitas dari penggunaan obat sefotaksim sebesar $76 \%$.

Tahapan kedua dari CEA adalah menghitung rasio efektivitas biaya (Average Cost-Effectiveness Ratio/ACER) dari setiap kelompok ampisilin dan sefotaksim. Dari hasil perhitungan dengan menggunakan rumus ACER (biaya total rata-rata terapi/efektivitas), maka nilai ACER pada pasien demam tifoid yang menggunakan obat sefotaksim sebesar Rp.1.571.014,474 sedangkan nilai ACER pada pasien yang menggunakan ampisilin sebesar Rp.2.629.026,316 (lebih jelas dapat dilihat pada Tabel 5).

Tahapan ketiga dari analisis ini adalah penentuan posisi alternatif pengobatan demam tifoid berdasarkan diagram efektivitas biaya (Gambar 1). ${ }^{11}$ Penentuan posisi alternatif pengobatan dilihat dari biaya rata-rata total terapi dan efektivitas. Alternatif terapi demam tifoid yang diinginkan dalam penelitiaan ini adalah sefotaksim. Berdasarkan Gambar 1 terlihat posisi sefotaksim terletak pada kolom I yang artinya sefotaksim memiliki efektivitas dan biaya yang tinggi dibandingkan dengan ampisilin, sehingga perlu untuk dilakukan perhitungan rasio inkremental efektivitas biaya (Incremental Cost-Effectiveness Ratio/ICER). Rumus yang digunakan untuk menghitung nilai ICER adalah rata-rata biaya total sefotaksim dikurangi rata-rata biaya total ampisilin dibagi dengan efektivitas sefotaksim dikurangi efektivitas ampisilin. Tampak pada Tabel 6 bahwa nilai ICER terapi ampisilin terhadap sefotaksim sebesar Rp.513.002,632 per efektivitas.

Tahapan analisis yang terakhir dilakukan adalah analisis sensitivitas. Tampak pada Tabel 7 bahwa setelah mengabaikan biaya rawat inap, terlihat nilai ACER terapi sefotaksim sebesar Rp.986.263,158 per efektivitas sedangkan ampisi- 
lin sebesar Rp.1.476.184,211 per efektivitas.

\section{PEMBAHASAN}

Angka kejadian demam tifoid terbanyak terjadi pada usia 1-5 tahun sebesar 53\%. Hal ini memperlihatkan usia di bawah 5 tahun lebih rentan untuk mengalami demam tifoid dibandingkan dengan usia $\geq 5$ tahun, dikarenakan bahwa anak-anak lebih menyukai bermain dan membeli jajanan di luar rumah yang higiennya tidak dapat dijamin. Anak-anak tersebut lebih rentan terhadap penyakit yang disebabkan oleh bakteri dibandingkan orang dewasa. Hal ini dikarenakan sistem kekebalan tubuh anak belum berfungsi secara sempurna, belum memperoleh berbagai antibodi yang diperlukan untuk menangkal infeksi, dan akibat pola tingkah laku anak yang lebih banyak berisiko terpapar bakteri. ${ }^{12}$

Pasien anak dengan jenis kelamin perempuan dan laki-laki tidak memiliki perbedaan untuk mengalami demam tifoid. Hal ini dikarenakan terbatasnya jumlah sampel yang diperoleh selama penelitian. Namun, beberapa penelitian menyimpulkan bahwa pasien anak berjenis kelamin laki-laki cenderung berisiko untuk mengalami demam tifoid dibandingkan perempuan. Hal ini disebabkan laki-laki memiliki aktivitas yang lebih tinggi dari perempuan dan kebiasan laki-laki yang kurang memperhatikan kesehatannya serta lebih menyukai jajan di jalan yang higiennya tidak dapat dijamin. ${ }^{13,14}$

Berdasarkan hasil karakteristik subyek menurut kelas perawatan, bahwa yang paling dominan digunakan oleh pasien anak demam tifoid peserta BPJS Kesehatan adalah kelas perawatan II. Hal ini menggambarkan bahwa penderita demam tifoid didominasi oleh masyarakat tidak mampu secara ekonomi yang memanfaatkan pelayanan jaminan kesehatan serta ketersediaan kelas I yang minimum.

Hasil karakteristik subyek berdasarkan frekuensi uji widal menunjukkan bahwa terdapat

\begin{tabular}{|c|c|c|c|}
\hline Efektivitas - Biaya & Biaya lebih rendah & Biaya sama & Biaya lebih tinggi \\
\hline Efektivitas lebih rendah & $\begin{array}{c}\mathrm{A} \\
\text { (Perlu perhitungan ICER) }\end{array}$ & $\mathrm{B}$ & $\begin{array}{c}\mathrm{C} \\
\text { (Dominan) }\end{array}$ \\
\hline Efektvitas sama & $\mathrm{D}$ & $\mathrm{E}$ & $\mathrm{F}$ \\
\hline Efektivitas lebih tinggi & $\begin{array}{c}\mathrm{G} \\
\text { (Dominan) }\end{array}$ & $\mathrm{H}$ & $\begin{array}{c}\text { I } \\
\text { (Perlu perhitungan ICER) }\end{array}$ \\
\hline
\end{tabular}

Gambar 1. Diagram Efektivitas Biaya ${ }^{11}$

Tabel 6. Hasil ICER

\begin{tabular}{cccccc}
\hline Pola terapi Antibiotik & $\begin{array}{c}\text { Biaya Medik Langsung } \\
(\mathbf{R p})\end{array}$ & $\begin{array}{c}\text { Efektivitas } \\
\mathbf{( \% )}\end{array}$ & $\Delta \mathbf{C}$ & $\Delta \mathbf{E}$ & $\begin{array}{c}\text { ICER } \\
\Delta \mathbf{C} / \Delta \mathbf{E}\end{array}$ \\
\hline Ampisilin & 999.030 & 38 & & & \\
Sefotaksim & 1.203 .383 & 76 & 204.353 & 38 & $5.377,71$ \\
\hline
\end{tabular}

Tabel 7. Simulasi terhadap Sensitivitas ACER Pasien Anak Demam Tifoid dengan Menggunakan Sefotaksim dan Ampisilin

\begin{tabular}{ccccc}
\hline Antibiotik & ACER awal & $\begin{array}{c}\text { Total Rata-Rata Biaya tanpa } \\
\text { Biaya Rawat Inap (Rp) }\end{array}$ & $\begin{array}{c}\text { Efektivitas } \\
\text { Terapi }\end{array}$ & ACER (Rp) \\
\hline Ampisilin & $2.629 .026,316$ & 560.950 & 0,38 & $1.476 .184,211$ \\
Sefotaksim & $1.571 .014,474$ & 749.560 & 0,76 & $986.263,158$ \\
\hline
\end{tabular}


$80 \%$ pasien anak demam tifoid melakukan uji widal 1 kali. Jika dalam 1 kali pengujian sudah memberikan hasil yang positif dengan ditandai adanya bakteri Salmonella typhi, maka pengujian tes widal cukup untuk dilakukan hanya 1 kali. Namun demikian, dari hasil penelitian yang diperoleh terdapat $20 \%$ pasien demam tifoid yang menjalani tes widal sebanyak 2 kali. Hal ini dikarenakan rendahnya sensitivitas dan spesifisitas dari pengujian. Tes ini dapat memberikan hasil negatif sampai $30 \%$ dari pembuktian tes kultur yang positif penyakit demam tifoid. Hal ini disebabkan karena pemberian terapi antibiotik sebelum pemeriksaan sehingga dapat menimbulkan respon antibodi. ${ }^{14}$

Berdasarkan tatalaksana pengobatan demam tifoid anak, RST TK II Kartika Husada Kubu Raya menggunakan terapi utama yaitu pemberian antibiotik dan terapi pendukung. Terapi pendukung diberikan untuk mengurangi dan mengatasi gejala serta keluhan-keluhan yang dirasakan pasien anak demam tifoid. Semua pasien anak demam tifoid diberikan cairan infus. Cairan infus yang digunakan adalah Ringer Laktat Obat Generik Berlogo (RL OGB). Cairan infus tersebut berguna sebagai cairan elektrolit yang menjaga keseimbangan air dan elektrolit atau bisa juga sebagai sumber energi. Pada penderita demam tifoid harus mendapatkan cairan yang cukup, baik secara oral maupun parenteral. ${ }^{15}$

Penggunaan obat analgetik antipiretik sebesar $100 \%$. Analgetika merupakan zat-zat yang dapat mengurangi rasa nyeri tanpa menghilangkan kesadaran. Obat ini diresepkan pada anak dengan penyakit demam tifoid karena salah satu gejala yang muncul pada pasien berupa demam dan nyeri kepala. Analgetik antipiretik yang digunakan adalah Parasetamol. Kadang-kadang masalah pencernaan terjadi ketika pasien mengalami demam tifoid dengan menunjukkan adanya mual, muntah, nyeri diperut, keluhan konstipasi maupun obstipasi dan kemudian disusul dengan episode diare. ${ }^{6,16}$ Pemberian obat laksatif untuk mengurangi gejala konstipasi. Selain itu, untuk memperbaiki gejala mual/muntah pada pasien diberikan terapi simptomatik yaitu antiemetik. Pemberian antiulserasi digunakan untuk menghilangkan gejala nyeri perut yang dialami pasien. Salah satu antagonis reseptor $\mathrm{H}-2$ yang paling banyak digunakan pada kelompok anak sebagai pengobatan standar terhadap ulkus peptikum adalah ranitidin. Ranitidin efektif untuk menghilangkan gejala nyeri pada episode akut dan mempercepat penyembuhan ulkus dengan toksisitas relatif ringan. ${ }^{17,18}$

Selanjutnya dilakukan analisis efektivitas biaya (Cost effectiveness Analysis/CEA). Berdasarkan hasil analisis tahap pertama diperoleh biaya total rata-rata terapi demam tifoid pada pasien yang menggunakan antibiotik sefotaksim lebih tinggi dibandingkan dengan sefotaksim. Disisi lain, efektivitas dari terapi sefotaksim lebih tinggi dibandingkan dengan terapi ampisilin. Biaya total rata-rata pada pasien demam tifoid yang menggunakan sefotaksim lebih tinggi dibandingkan ampisilin dikarenakan harga obat sefotaksim lebih mahal dibandingkan ampisilin. Selain itu, kelas perawatan juga menjadi faktor yang memengaruhi biaya perawatan. Pasien yang menggunakan sefotaksim lebih banyak memilih di rawat inap pada kelas perawatan I dan kelas perawatan II sehingga tarif yang dikeluarkan juga semakin besar. Dari segi efektivitas, sefotaksim diketahui lebih efektif dibandingkan ampisilin dalam mencapai target waktu bebas demamnya selama 4-14 hari. ${ }^{19,20}$

Penelitian yang dilakukan oleh Fithria dkk., di Puskesmas Bancak Kabupaten Semarang pada tahun 2014 mengemukakan bahwa lama perawatan yang paling singkat terdapat pada pasien dengan terapi seftriakson, kemudian diikuti amoksisilin, sefotaksim, kloramfenikol, dan ampisillin. Efektivitas sefotaksim yang lebih baik dibandingkan ampisilin disebabkan oleh sefotaksim memiliki spektrum kerja yang sangat luas. Aktivitas antibakteri sefotaksim lebih kuat dan efek sampingnya relatif lebih rendah. Namun dari segi harga, sefotaksim diketahui memiliki harga lebih mahal dibandingkan ampisillin. ${ }^{21}$ Dari hasil perhitungan rasio efektivitas biaya (Average Cost-Effectiveness Ratio/ACER) memperlihatkan terapi sefotaksim memiliki efektivitas biaya lebih rendah dibandingkan dengan terapi ampisilin. Artinya, penggunaan sefotaksim untuk terapi demam tifoid lebih cost effective dibandingkan dengan penggunaan ampisilin. Hal yang sama juga disimpulkan oleh penelitian Susono dkk., bahwa sefotaksim cost effective sebagai terapi demam tifoid anak. ${ }^{22}$

Hasil penentuan posisi alternatif pengobatan demam tifoid berdasarkan diagram efektivitas biaya (Gambar 1) diketahui posisi sefotak- 
sim terletak pada kolom I yang artinya sefoktaksim memiliki efektivitas dan biaya yang tinggi dibandingkan dengan ampisilin. Setelah diketahui posisi sefotaksim berada di kolom I maka perlu untuk dilakukan perhitungan rasio inkremental efektivitas biaya (Incremental Cost-Effectiveness Ratio/ ICER). ICER digunakan untuk mendeterminasi biaya tambahan untuk setiap pertambahan efektivitas dari suatu terapi. Nilai ICER yang diperoleh sebesar Rp.513.002,632 per efektivitas. Nilai ICER tersebut memperlihatkan bahwa adanya tambahan biaya yang diperlukan jika akan dilakukan perpindahan terapi dari ampisilin ke sefotaksim. Jika rumah sakit menginginkan peningkatan efektivitas penyembuhan demam tifoid per pasien dengan menggunakan sefotaksim, maka rumah sakit harus mengeluarkan biaya sebesar Rp.513.002,632. Namun demikian, dalam pengambilan keputusan pemilihan penggunaan antibiotik pada pasien anak demam tifoid dapat dikembalikan lagi kepada kebijakan pihak rumah sakit yang disesuaikan dengan anggaran rumah sakit tersebut.

Tahapan analisis selanjutnya adalah dilakukan analisis sensitivitas. Cara menganalisis sensitivitas yaitu menghitung ulang (ACER) dari masing-masing output setiap alternatif dengan melakukan simulasi dengan mengeluarkan satu atau lebih variabel biaya sehingga nilainya dapat berubah. Pengeluaran satu variabel biaya dilakukan pada biaya rawat inap pasien. Dari hasil analisis sensitivitas menunjukkan sefotaksim lebih cost effective dibandingkan ampisilin dengan melihat nilai ACER dari penggunaan sefotaksim lebih rendah (Rp.986.263,158 per efektivitas) dibandingkan dengan nilai ACER ampisilin (Rp.1.476.184,211 per efektivitas). Dari hasil analisis sensitivitas yang dilakukan secara bermakna menunjukkan penggunaan sefotaksim lebih cost effective dibandingkan ampisilin dalam terapi demam tifoid anak.

\section{KESIMPULAN DAN SARAN}

Berdasarkan hasil penelitian, persentase efektivitas lama rawat inap pasien demam tifoid yang memenuhi target pengobatan selama 4-14 hari pada penggunaan antibiotik sefotaksim sebesar $76 \%$ dan ampisilin sebesar 38\%. Penggunaan antibiotik sefotaksim dengan biaya sebesar Rp.1.571.014,474 per efektivitas lebih cost ef- fective dibandingkan dengan penggunaan ampisilin yaitu sebesar Rp.2.629.026,316 per efektivitas pada pasien anak demam tifoid di RST TK II Kartika Husada Kubu Raya. Biaya tambahan yang dikeluarkan rumah sakit jika terjadi perpindahan terapi dari penggunaan ampisilin ke sefotaksim sebesar Rp.513.002,632 untuk setiap peningkatan efektivitas. Adapun saran dari penelitian ini, yaitu perlu dilakukannya penelitian mengenai analisis efektivitas biaya penggunaan antibiotik dengan parameter hasil laboratorium dari uji widal pada pasien demam tifoid.

\section{DAFTAR PUSTAKA}

1. Geoffrey CB, Christa LFW, Robert EB. Typhoid fever and paratyphoid fever: Systematic review to estimate global morbidity and mortality for 2010. J Glob Health. 2012 Jun;2(1): 010401.

2. Badan Penelitian dan Pengembangan Kesehatan. Riset Kesehatan Dasar. Jakarta: Departemen Kesehatan RI; 2008.

3. Badan Penelitian dan Pengembangan Kesehatan. Riset Kesehatan Dasar. Jakarta: Departemen Kesehatan RI; 2010.

4. Karyanti MR. Pemeriksaan Diagnostik Terkini untuk Demam Tifoid. Dalam Hardinegoro SR, Kadim M, Devaera Y, Idris AS, Ambarsari CG. Update Management of Infectious Disease and Gastrointestinal Disorders. Jakarta: Departemen Ilmu Kesehatan Anak FKUIRSCM; 2012. h. 1-8.

5. Prayitno A. Pilihan Terapi Antibiotik untuk Demam Tifoid. Dalam Hardinegoro SR, Ka$\operatorname{dim}$ M, Devaera Y, Idris AS, Ambarsari CG. Update Management of Infectious Disease and Gastrointestinal Disorders. Jakarta: Departemen Ilmu Kesehatan Anak FKUI-RSCM; 2012. h. 9-15.

6. Juwono R, Prayitno A. Terapi Antibiotik. Dalam Aslam M, Tan CK, Prayitno A. Farmasi Klinik Menuju Pengobatan Rasional dan Penghargaan Pasien. Jakarta: PT. Elex Media Komputindo Kelompok Gramedia; 2003. h. 321.

7. Andi Evi Erviani. Analisis Multidrug Resistensi terhadap Antibiotik pada Salmonella typhi dengan Teknik Multiplex PCR. Biogenesis. 2013 Jun;1(1):51-60. 
8. Musnelina L, Afdhal AF, Gani A, Andayani P. Pola Pemberian Antibiotik Pengobatan Demam Tifoid Anak di Rumah Sakit Fatmawati Jakarta 2001-2002. Makara Kesehatan. 2004 Jun;8(1):27-31.

9. Chowta MN, Chowta NK. Study of Clinical Profile and Antibiotic Response in Typhoid Fever. Indian J Med Microbiol. 2005 Apr; 23(2):125-127.

10. Gopal M, Arumugam S, Gnadesikan S, Ramesh S. Studies on Antimicrobial Susceptibility Pattern of Salmonella typhi Isolates from Chennai, India. Int J of Pharma and Bio Sci. April-Juni 2011;2(2):B-435 - B-442.

11. Kemenkes RI. Pedoman Penerapan Kajian Farmakoekonomi. Jakarta: Kementerian Kesehatan Republik Indonesia; 2012.

12. Shea K, Florini K, Barlam T. When Wonder Drugs Don't Work: How Antibiotic Resistance Threatens Children, Seniors, And The Medically Vulnerable. Washington, DC: Environmental Defense; 2002.

13. Maria H, Lannywati G. Hubungan Faktor Determinan dengan Kejadian Tifoid di Indonesia Tahun 2007. Media Peneliti dan Pengembangan Kesehatan. 2009;XIX(4):65-173.

14. Okky P. Faktor Risiko Kejadian Penyakit Demam Tifoid pada Penderita yang Dirawat di Rumah Sakit Umum Daerah Ungaran. Jurnal Kesehatan Masyarakat. 2013;2(1).

15. WHO. The Diagnosis, Treatment, and Prevention of Thypoid Fever. Geneva: Department of
Vaccines and Biologicals; 2003. h. 11-16.

16. Depkes RI. Pedoman Pengendalian Demam Tifoid. Jakarta: Direktorat Jendral PP \& PL; 2006.

17. Sumarmo SPS, Herry Garna, S Hadinegoro. Buku Ajar Ilmu Kesehatan Anak Infeksi dan Penyakit Tropis Edisi Pertama. Jakarta: IDAI; 2002. h. 367-375.

18. Noval A. Peran Antagonis Reseptor H-2 dalam Pengobatan Ulkus Peptikum. Sari Pediatri. 2002 Maret;3(4):222-226.

19. Scioli C, Giusti G, Balestrieri G. Comparison of Ampicillin and Chloramphenicol in Treatment of Typhoid Fever. Postgrad Med J. 1964 Des; 40:87-91.

20. Park SC, Lee CH, Kim SY, Park CH, Kim TW, Seok SE, et al. Clinical Trial of Cefotaxime in Patients with Typhoid Fever. Clin Ther [Abstract]. 1985;7(4):448-451.

21. Fithria RF, Damayanti K, dan Fauziah RP. Perbedaan Efektivitas Antibiotik pada Terapi Demam Tifoid di Puskesmas Bancak Kabupaten Semarang Tahun 2014. Semarang: Fakultas Farmasi Universitas Wahid Hasyim; 2015.

22. Susono RF, Sudarso S, Galistiani GF. Cost Effectiveness Analysis Pengobatan Pasien Demam Tifoid Pediatrik Menggunakan Cefotaxime dan Chloramphenicol di Instalasi Rawat Inap RSUD Prof. Dr. Margono Soekarjo. Jurnal Pharmacy [Abstrak]. 2014 Jul; 11(01). 